\title{
Dormancy in native fruit seeds of the Brazilian South Region
}

Kelli Pirola, Américo Wagner Junior, Marcelo Dotto, Darcieli Aparecida Cassol, Jean Carlo Possenti, Idemir Citadin

Universidade Tecnológica Federal do Paraná - UTFPR, PR. E-mail: kelli pirola1@hotmail.com

\begin{abstract}
The aim of the present study was to investigate whether seeds from six native fruit species of the South Brazilian region had any type of dormancy, as well as, to verify if they have photoblastism. The work was carried out at the Plant Physiology Laboratory of the Federal Technological University of Paraná - Câmpus Dois Vizinhos, Paraná State, Brazil. The influence of photoperiod factors and techniques for overcoming dormancy were tested on the germination of Eugenia uniflora L. (Surinan cherry), Plinia peruviana (native jabuticaba), Plinia cauliflora (hybrid jabuticaba), Eugenia involucrata DC. (Rio Grande cherry), Myrcianthes pungens (guabiju) and Campomanesia guazumifolia (sete capoteiro). The seeds were exposed in a condition of total darkness or photoperiod of 24 hours, being the levels of one of factors tested. The techniques for breaking dormancy tested were the immersion in gibberellic acid solution ( $\left.200 \mathrm{mg} \mathrm{L}^{-1}\right)$; stratification at $5{ }^{\circ} \mathrm{C}$ for 30 days; immersion in water at room temperature for 24 hours; immersion in hot water $\left(80^{\circ} \mathrm{C}\right)$ for five minutes; immersion in sulfuric acid solution $(96 \%)$ for five minutes; and manual physical scarification with 120 grit sandpaper. The seeds were also tested without using any technique, making up the controls treatments with or without light. The experimental design was completely randomized, in a $2 \times 7$ factorial scheme (luminosity $\times$ treatment for breaking dormancy), with four replications of 100 seeds. After 60 days, germination (\%), percentage of accumulated germination, germination speed index and average germination time were analyzed. The seeds of most of the studied native species do not present dormancy or the effect of photoblastism, except for "sete capoteiro" seeds who are supposed to have morphophysiological dormancy, with negative photoblastism. The use of hot water or sulfuric acid in the seeds of native fruit trees is not recommended.
\end{abstract}

Keywords: Myrtaceae; photoperiod; sexual propagation.

\section{Dormência em sementes de frutas nativas da Região Sul do Brasil}

\section{Resumo}

O objetivo do presente estudo foi investigar se sementes de seis fruteiras nativas da região Sul do Brasil apresentavam algum tipo de dormência, bem como verificar a existência ou não de fotoblastismo. 0 trabalho foi realizado no Laboratório de Fisiologia Vegetal, da Universidade Tecnológica Federal do Paraná Câmpus Dois Vizinhos. A influência do fotoperíodo e das técnicas para superação da dormência foram testadas para Eugenia uniflora L. (pitangueira), Plinia peruviana (jabuticabeira nativa), Plinia cauliflora (jabuticabeira híbrida), Eugenia involucrata DC. (cerejeira do Rio Grande), Myrcianthes pungens (guabijuzeiro) e Campomanesia guazumifolia (sete capoteiro). As sementes foram expostas em condição de escuridão total ou fotoperíodo de 24 horas, sendo estes, níveis de um dos fatores testados. Também foram testadas técnicas de superação de dormência como de imersão em solução de ácido giberélico $\left(200 \mathrm{mg} \mathrm{L}^{-1}\right)$; estratificação a $5{ }^{\circ} \mathrm{C}$ por 30 dias; imersão em água em temperatura ambiente por 24 horas; imersão em água quente $\left(80^{\circ} \mathrm{C}\right)$ por cinco minutos; imersão em solução de ácido sulfúrico (96\%) por cinco minutos e escarificação física manual com lixa 120. As sementes também foram testadas sem uso de técnicas para quebra de dormência, constituindo-se os tratamentos testemunhas com e sem luz. $O$ delineamento experimental foi inteiramente casualizado, em esquema fatorial $2 \times 7$ (luminosidade $x$ tratamento para quebra de dormência), com quatro repetições de 100 sementes. Após 60 dias, foram analisados a germinação (\%), a porcentagem de germinação acumulada, o índice de velocidade de germinação e o 
tempo médio de germinação. As sementes da maioria das espécies nativas estudadas não apresentam dormência ou efeito de fotoblastismo, exceto "sete capoteiro" que supostamente apresenta sementes com dormência morfofisiológica, com fotoblastismo negativo. O uso de água quente ou ácido sulfúrico nas sementes de fruteiras nativas não é recomendado.

Palavras-chave: Myrtaceae; fotoperíodo; propagação sexuada.

\section{Introduction}

Brazil stands out as one of the main centers of genetic diversity of wild fruit in the world. However, little is known about most of these species. In the South of the country, native fruit trees play an important role with great potential for economic exploitation, being the most prominent species the ones of Myrtaceae family such as Eugenia uniflora L. (Surinan cherry), Plinia peruviana (native "jabuticaba"), Plinia cauliflora (hybrid "jabuticaba"), Eugenia involucrata DC. (Rio Grande cherry), Myrcianthes pungens ("guabiju") and Campomanesia guazumifolia ("sete capoteiro") (FRANZON, 2008).

One of the problems faced for the expansion of the commercial orchards of these fruit species is obtaining seedlings of good quality, since the plant propagation of the through vegetative techniques, still needs much research and improvement.

Thus, the seed propagation still prevails, despite all the implications that this technique may have. There are several reports that describe the influence of temperature, light, substrate, humidity and the fruit maturation stage in the germination processes of some of these species (VALIO; FERREIRA, 1992; ANDRADE; MARTINS, 2003; ALEXANDRE et al., 2004; SENA et al., 2010).

However, there are still doubts related to the existence or not of dormancy in their seeds since some have shown delays in the beginning of germination, which is supposedly due to dormancy. The available works on the subject are not conclusive. For seeds of "jabuticaba", for example, Wagner Júnior et al. (2011), reported the beginning of germination at 27 days after sowing. For "sete capoteiro", the seed germination time is even longer, occurring after 90 days, (SANTOS et al., 2004). However, both works did not conclude on seed dormancy.

The seed dormancy in a natural environment is important, as it allows the species to distribute its germination over time and in space, increasing the chance of guaranteeing perpetuation (PIÑA-RODRIGUES; AGUIAR, 1993). However, when commercial production is sought, it becomes an obstacle, due to the long time required to obtain seedlings, coupled with the fact that during this period there is consumption of reserves, which can lead to losses in the quality of the emerged seedling (BORGES et al., 1982).

Fowler and Bianchetti (2000) describe three types of endogenous dormancy in seeds classified as physiological, morphological and morphophysiological. Likewise chemical, physical and mechanical dormancy can be classified as types of exogenous dormancy. A dormant seed will only be able to germinate after the effect of such mechanism is extinguished (DIAS, 2005).

Among the most common processes for overcoming seed dormancy are the chemical and physical scarification, tegument rupture, cold and/or hot stratification, thermal shock, exposure to intense light, immersion in hot water and imbibition in cold water (FOWLER; BINCHETTI, 2000). Thus, in order to advance scientific knowledge in seed technology of the referred species, it is necessary to first identify whether their seeds have dormancy, what the mechanism or type of dormancy is involved and how to overcome it. In this way, conditions are being provided to encourage the use of these fruit trees in orchards, either domestic or commercial.

The objective of the work was to verify if the seeds of six Brazilian native fruit species present any type of dormancy, and if so, to characterize its nature in order of establishing techniques to overcome it. Another goal was to verify the existence or not of photoblastism in the seeds of Brazilian native fruits.

\section{Material and Methods}

The work was carried out at the Plant Physiology Laboratory of the Universidade Tecnológica Federal do Paraná - Câmpus Dois Vizinhos. As experimental material, seeds were obtained from physiologically mature fruits of Eugenia uniflora L. (Surinan cherry), Plinia 
peruviana (native "jabuticaba"), Plinia cauliflora (hybrid "jabuticaba"), Eugenia involucrata DC (Rio Grande cherry), Myrcianthes pungens ("guabiju") and Campomanesia guazumifolia ("sete capoteiro"). The fruits were collected manually according to their maturation time in native plants located in rural properties in the
Southwest region of Paraná State. Table 1 presented the locations and dates of fruit harvesting, as well as their georeferenced coordinates. Fruits were harvested randomly from well developed trees and with good phytosanitary condition.

Table 1. Native fruit tree, month and year of the harvest, harvest place and the geographic coordinates of each region.

\begin{tabular}{|c|c|c|}
\hline Native fruit tree & $\begin{array}{l}\text { Month/Year of } \\
\text { harvesting }\end{array}$ & City /Coordinates \\
\hline Native "jabuticaba" & September/2011 & $\begin{array}{c}\text { Pato Branco (Latitude } 26^{\circ} 15^{\prime} 13.11^{\prime \prime S} / \\
\text { Longitude } 52^{\circ} 37^{\prime} 18.00^{\prime \prime O} \text { ) }\end{array}$ \\
\hline Hybrid Jabuticaba & September /2011 & $\begin{array}{l}\text { Pérola D' Oeste (Latitude } 25^{\circ} 48^{\prime} 55.08^{\prime \prime} \mathrm{S} / \\
\text { Longitude } 53^{\circ} 45^{\prime} 14.42^{\prime \prime O} \text { ) }\end{array}$ \\
\hline Surinan Cherry & October/2011 & $\begin{array}{c}\text { Pato Branco (Latitude } 26^{\circ} 14^{\prime} 28.41^{\prime \prime} \mathrm{S} / \\
\left.\text { Longitude } 52^{\circ} 35^{\prime} 24.55^{\prime \prime} \mathrm{O}\right)\end{array}$ \\
\hline Rio Grande cherry & September /2011 & $\begin{array}{c}\text { Dois Vizinhos (Latitude } 25^{\circ} 44^{\prime} 32.46^{\prime \prime} \mathrm{S} / \\
\left.\text { Longitude } 53^{\circ} 3^{\prime} 22.79^{\prime \prime} \mathrm{O}\right)\end{array}$ \\
\hline "Guabiju" & December/2011 & $\begin{array}{c}\text { Pato Branco (Latitude } 26^{\circ} 13^{\prime} 28.74^{\prime \prime S} / \\
\text { Longitude } 52^{\circ} 40^{\prime} 34.86^{\prime \prime O} \text { ) }\end{array}$ \\
\hline "Sete-capoteiro" & February/2012 & $\begin{array}{c}\text { Pato Branco (Latitude } 26^{\circ} 15^{\prime} 48.05^{\prime \prime S} / \\
\text { Longitude } 52^{\circ} 33^{\prime} 8.07^{\prime \prime} \mathrm{O} \text { ) }\end{array}$ \\
\hline
\end{tabular}

For seed extraction of "guabiju", Rio Grande cherry and Surinan cherry, the pulp was manually removed whereas for native and hibryd "jabuticabas" and, "sete capoteiro", the pulp was rubbed in a fine mesh sieve, adding lime (HOSSEL et al., 2013). Subsequently, the seeds of all species, were washed in running water for the pulp complete removal. Then, they were placed on paper towels, where they remained in a natural environment for 24 hours, on the shade, to remove excess moisture.

The experimental design was completely randomized, in a $2 \times 7$ factorial (photoperiod $x$ technique for seed break dormancy), with four replications, of 100 seeds each, which constituted the experimental units. Regarding the photoperiod, the seeds were submitted during the germination process either to total darkness or to 24 hours photoperiod of $6.000 \mathrm{~K}$ white fluorescent light. The techniques applied to overcome possible physiological dormancy were the use of gibberellic acid $\left(200 \mathrm{mg} \mathrm{L}^{-1}\right)$ for one hour in the seeds and stratification at $5^{\circ} \mathrm{C}$ for 30 days; for possible overcoming of physical dormancy, the seeds were immersed in water at room temperature for 24 hours, in hot water ( 80 ${ }^{\circ} \mathrm{C}$ ) for five minutes, in sulfuric acid $(96 \%)$ for five minutes and scarification with sandpaper 120.
The control treatment did not suffer no technique to overcome numbness and was subjected to only two levels of the photoperiod factor.

The gibberellic acid (GA3) solution was prepared from the commercial product Pro$\mathrm{Gibb}^{\circledR}(10 \% \mathrm{GA} 3)$. The volume of water used in the immersion tests was four times greater than the volume of the seeds and when the sulfuric acid was applied the volume of water was twice greater than the volume of the seeds. The seed treated with sulfuric acid were washed in water until the product is completely removed (ANDRADE et al., 1997).

After the application of each technique, the seeds were placed to germinate in transparent polypropylene boxes (gerbox type) with $11 \times 11 \times 11 \mathrm{~cm}$ dimensions and with a lid. Two sheets of blotting paper, moistened with 2.5 times their weight with distilled water, were used as substrate, according to the RAS (BRASIL, 2009). Each gerbox represented an experimental unit and was taken to a B.O.D. at a constant temperature of $25{ }^{\circ} \mathrm{C}$, as recommended by Wagner Júnior et al. (2007). The substrate was remoistened as needed, by visual verification.

Sixty days after the first germinated seed, with the exception of the "sete capoteiro" which 
was after 126 days, the germination percentage (G\%) according to the RAS (BRASIL, 2009); germination speed index (GSI) according to Maguire (1962), percentage of accumulated germination (GA\%); average germination time (TMG), according to Silva and Nakagawa (1995) were evaluated. After compiling the data set, they were submitted to the Lilliefors Normality Test.

The G\% and TMG data were transformed into arc sine $\sqrt{x / 100}$ and the GSI into $\sqrt{x+1}$. The results were submitted to a variance analysis and when significant, the means were compared by Tukey's test at $5 \%$ probability. All analysis were performed using the SANEST ${ }^{\circledast}$ computational application (ZONTA; MACHADO, 1984).

\section{Results and Discussion}

It was observed that the treatment effects and their interactions occurred differently according to the species. The interaction of the photoperiod $x$ technical factors for overcoming dormancy was shown to be significant for G\% and GSI in the seeds of "sete capoteiro" and Rio Grande cherry (Tables 2 and 4), "guabiju", hybrid and native "jabuticabas" (Tables 3 and 5). For Surinan cherry seeds there was significance for germination and GSI only for the technical factor of breaking dormancy (Table 6). For the average germination time (TMG), the interaction was significant for the hybrid "jabuticaba", "guabiju", "sete capoteiro" and Surinan cherry (Tables 7 and 8). For the Rio Grande cherry seeds, there was significance only for the isolated dormancy breaking factor (Table 9), and for native "jabuticaba"seeds there was significance for the dormancy breaking and photoperiod factors alone but there was no significant interaction (Tables 9 and 10).

Table 2. Germination (\%) of "sete capoteiro" (C. guazumifolia) and Rio Grande cherry (E. involucrata) seeds, according to the breaking dormancy technique and photoperiod ( 0 and 24 hours).

\begin{tabular}{c|cc|cc}
\hline \multirow{2}{*}{ Treatment } & \multicolumn{2}{|c|}{ “Sete capoteiro" } & \multicolumn{2}{c}{ Rio Grande cherry } \\
\cline { 2 - 5 } & 0 hours & 24 hours & 0 hours & 24 hours \\
\hline T1 & $19.88 \mathrm{a} \mathrm{A}^{* *}$ & $2.03 \mathrm{a} \mathrm{B}$ & $98.06 \mathrm{a} \mathrm{A}$ & $92.85 \mathrm{bA}$ \\
T2 & $24.11 \mathrm{a} \mathrm{A}$ & $0.00 \mathrm{a} \mathrm{B}$ & $98.92 \mathrm{a} \mathrm{A}$ & $95.45 \mathrm{aA}$ \\
T3 & $5.77 \mathrm{bc} \mathrm{A}$ & $0.00 \mathrm{a} \mathrm{A}$ & $64.75 \mathrm{~b} \mathrm{~A}$ & $30.11 \mathrm{cB}$ \\
T4 & $15.81 \mathrm{ab} \mathrm{A}$ & $0.00 \mathrm{a} \mathrm{B}$ & $100.00 \mathrm{a} \mathrm{A}$ & $98.60 \mathrm{aA}$ \\
T5 & $0.00 \mathrm{c} \mathrm{A}$ & $0.00 \mathrm{a} \mathrm{A}$ & $0.00 \mathrm{c} \mathrm{A}$ & $0.00 \mathrm{dA}$ \\
T6 & $17.83 \mathrm{a} \mathrm{A}$ & $8.46 \mathrm{a} \mathrm{B}$ & $98.54 \mathrm{a} \mathrm{A}$ & $91.71 \mathrm{bB}$ \\
T7 & $0.00 \mathrm{c} \mathrm{A}$ & $0.00 \mathrm{a} \mathrm{A}$ & $0.00 \mathrm{c} \mathrm{A}$ & $0.00 \mathrm{dA}$ \\
\hline CV (\%) & \multicolumn{3}{c}{10.75} \\
\hline
\end{tabular}

* $\mathrm{T} 1=$ No usage e of breaking dormancy; $\mathrm{T} 2=$ Gibberellic acid $\left(200 \mathrm{mg} \mathrm{L}{ }^{-1}\right)$ for one hour; $\mathrm{T} 3=$ Stratification at $5^{\circ} \mathrm{C}$ for 30 days; T4 = Immersion in water at room temperature for 24 hours; T5 = Chemical scarification with sulfuric acid $(96 \%)$ for 5 minutes; T6 = Scarification sandpaper; T7 = Immersion in hot water $\left(80^{\circ} \mathrm{C}\right)$ for 5 minutes.

** Averages with different letters, lower case in the same column and upper case in the same line differ by Tukey's test $(\alpha=0.05)$. 
Table 3. Germination (\%) of "guabiju" ( $M$. pungens), native "jabuticaba" ( $P$. peruviana) and hybrid "jabuticaba" ( $P$. cauliflora) seeds according to the breaking dormancy technique and photoperiod ( 0 and 24 hours).

\begin{tabular}{|c|c|c|c|c|c|c|}
\hline \multirow{2}{*}{ Treatment } & \multicolumn{2}{|c|}{ “Guabiju” } & \multicolumn{2}{|c|}{ Hybrid "jabuticaba" } & \multicolumn{2}{|c|}{ Native "jabuticaba" } \\
\hline & 0 hours & 24 hours & 0 hours & 24 hours & 0 hours & 24 hours \\
\hline T1* & $33.11 \mathrm{~b} \mathrm{~B}^{* *}$ & 50.00 a $A$ & $2.08 \mathrm{bc} \mathrm{B}^{* *}$ & 85.53 a $A$ & 90.12 a $A^{* *}$ & 80.36 a B \\
\hline $\mathrm{T} 2$ & 39.36 b A & 49.21 a A & $5.90 \mathrm{~b} \mathrm{~B}$ & 82.16 a $A$ & 92.75 a A & 78.48 a B \\
\hline T3 & $3.41 \mathrm{c} \mathrm{A}$ & $1.72 \mathrm{~d} A$ & 32.86 a B & $56.40 \mathrm{~b} \mathrm{~A}$ & $0.00 \mathrm{~b} \mathrm{~A}$ & $0.00 \mathrm{cA}$ \\
\hline T4 & 60.55 a A & $40.47 a b B$ & 8.65 b B & 87.72 a A & 86.81 a A & 40.75 b B \\
\hline T5 & $0.00 \mathrm{~d} A$ & $0.00 \mathrm{~d} A$ & 0.00 c A & $0.00 \mathrm{c} \mathrm{A}$ & $0.00 \mathrm{~b} \mathrm{~A}$ & $0.00 \mathrm{cA}$ \\
\hline T6 & $26.10 \mathrm{bA}$ & 29.80 b A & 42.06 a B & $74.77 \mathrm{ab} A$ & 89.30 a $\mathrm{A}$ & 73.50 a B \\
\hline T7 & $28.82 \mathrm{~b} \mathrm{~A}$ & 9.18 c B & 0.00 c A & 0.00 c A & $0.00 \mathrm{~b} \mathrm{~A}$ & 0.00 c A \\
\hline CV (\%) & \multicolumn{2}{|c|}{23.76} & \multicolumn{2}{|c|}{27.56} & \multicolumn{2}{|c|}{14.42} \\
\hline
\end{tabular}

* $\mathrm{T} 1=$ No usage of breaking dormancy; $\mathrm{T} 2=$ Gibberellic acid $\left(200 \mathrm{mg} \mathrm{L}^{-1}\right)$ for one hour; $\mathrm{T} 3=$ Stratification at $5{ }^{\circ} \mathrm{C}$ for 30 days; T4 = Immersion in water at room temperature for 24 hours; T5 = Chemical scarification with sulfuric acid (96\%) for 5 minutes; $\mathrm{T} 6=$ Scarification sandpaper; $\mathrm{T} 7=\mathrm{Immersion}$ in hot water $\left(80^{\circ} \mathrm{C}\right)$ for 5 minutes.

** Averages with different letters, lower case in the same column and upper case in the same line differ by Tukey's test $(\alpha=0.05)$.

Table 4. Germination speed index (GSI) of "sete capoteiro" (C. guazumifolia) and Rio Grande cherry (E. involucrata) according to the break dormancy technique and photoperiod ( 0 and 24 hours).

\begin{tabular}{c|cc|cc}
\hline \multirow{2}{*}{ Treatment } & \multicolumn{2}{|c|}{ "Sete capoteiro" } & \multicolumn{2}{c}{ Rio Grande cherry } \\
\cline { 2 - 5 } & 0 hours & 24 hours & 0 hours & 24 hours \\
\hline T1* & $0.06 \mathrm{ab} \mathrm{A}$ & $0.00 \mathrm{a} \mathrm{B}$ & $4.51 \mathrm{~b} \mathrm{~A}^{* *}$ & $4.59 \mathrm{a} \mathrm{A}$ \\
T2 & $0.08 \mathrm{a} \mathrm{A}$ & $0.00 \mathrm{a} \mathrm{B}$ & $4.96 \mathrm{ab} \mathrm{A}$ & $4.70 \mathrm{a} \mathrm{A}$ \\
T3 & $0.01 \mathrm{~cd} \mathrm{~A}$ & $0.00 \mathrm{a} \mathrm{A}$ & $1.96 \mathrm{c} \mathrm{A}$ & $1.05 \mathrm{~b} \mathrm{~B}$ \\
T4 & $0.04 \mathrm{bc} \mathrm{A}$ & $0.00 \mathrm{a} \mathrm{B}$ & $5.05 \mathrm{ab} \mathrm{A}$ & $4.68 \mathrm{a} \mathrm{A}$ \\
T5 & $0.00 \mathrm{~d} \mathrm{~A}$ & $0.00 \mathrm{a} \mathrm{A}$ & $0.00 \mathrm{~d} \mathrm{~A}$ & $0.00 \mathrm{c} \mathrm{A}$ \\
T6 & $0.06 \mathrm{ab} \mathrm{A}$ & $0.02 \mathrm{a} \mathrm{B}$ & $5.30 \mathrm{a} \mathrm{A}$ & $4.62 \mathrm{a} \mathrm{B}$ \\
T7 & $0.00 \mathrm{~d} \mathrm{~A}$ & $0.00 \mathrm{a} \mathrm{A}$ & $0.00 \mathrm{~d} \mathrm{~A}$ & $0.00 \mathrm{c} \mathrm{A}$ \\
\hline CV (\%) & \multicolumn{3}{c}{5.05} \\
\hline
\end{tabular}

${ }^{*} \mathrm{~T} 1=$ without breaking dormancy agent; $\mathrm{T} 2=$ Gibberellic acid $\left(200 \mathrm{mg} \mathrm{L}^{-1}\right)$ for one hour; $\mathrm{T} 3=$ Stratification at $5{ }^{\circ} \mathrm{C}$ for 30 days; $\mathrm{T} 4=$ Immersion in water at room temperature for 24 hours; $\mathrm{T} 5=$ Chemical scarification with sulfuric acid (96\%) for 5 minutes; $\mathrm{T} 6=$ Scarification sandpaper; $\mathrm{T} 7=$ Immersion in hot water $\left(80^{\circ} \mathrm{C}\right)$ for 5 minutes.

${ }^{* *}$ Averages with different letters, lower case in the same column and upper case in the same line differ by Tukey's test $(\alpha=0.05)$.

Table 5. Germination speed index (GSI) of "guabiju" seeds ( $M$. pungens), native "jabuticaba" ( $P$. peruviana) and hybrid "jabuticaba" ( $P$. cauliflora), according to the break dormancy technique and photoperiod ( 0 and 24 hours).

\begin{tabular}{|c|c|c|c|c|c|c|}
\hline \multirow{2}{*}{ Treatment } & \multicolumn{2}{|c|}{ "Guabiju" } & \multicolumn{2}{|c|}{ Hybrid "jabuticaba" } & \multicolumn{2}{|c|}{ Native "jabuticaba" } \\
\hline & 0 hours & 24 hours & 0 hours & 24 hours & 0 hours & 24 hours \\
\hline T1* & $1.52 \mathrm{~b} \mathrm{~B}^{* *}$ & 2.73 a $A$ & $0.19 \mathrm{~b} \mathrm{~B}^{* *}$ & $4.05 \mathrm{c} \mathrm{A}$ & 7.67 a $A^{* *}$ & 4.94 a B \\
\hline $\mathrm{T} 2$ & $2.22 \mathrm{~b} \mathrm{~B}$ & 3.05 a A & 0.16 b B & $4.96 \mathrm{~b} \mathrm{~A}$ & 7.57 a $A$ & 6.10 a A \\
\hline T3 & $0.22 \mathrm{c} \mathrm{A}$ & $0.06 \mathrm{c} \mathrm{A}$ & 3.60 a B & 6.77 a A & 0.00 c A & 0.00 c A \\
\hline T4 & 4.77 a $A$ & 2.71 a $B$ & 0.86 b B & $4.68 \mathrm{~b} \mathrm{~A}$ & $4.29 \mathrm{~b} \mathrm{~A}$ & $1.80 \mathrm{~b} \mathrm{~B}$ \\
\hline T5 & 0.00 c A & $0.00 \mathrm{cA}$ & $0.00 \mathrm{~b} \mathrm{~A}$ & $0.00 \mathrm{~d} A$ & $0.00 \mathrm{cA}$ & 0.00 c A \\
\hline T6 & $1.70 \mathrm{~b} \mathrm{~A}$ & $1.87 \mathrm{~b} \mathrm{~A}$ & 3.40 a A & $3.82 \mathrm{c} \mathrm{A}$ & 7.60 a A & 5.98 a B \\
\hline $\mathrm{T7}$ & $1.61 \mathrm{~b}$ A & 0.51 c B & $0.00 \mathrm{~b} \mathrm{~A}$ & $0.00 \mathrm{~d} A$ & 0.00 c A & 0.00 c A \\
\hline CV (\%) & \multicolumn{2}{|c|}{32.56} & \multicolumn{2}{|c|}{17.44} & \multicolumn{2}{|c|}{10.16} \\
\hline
\end{tabular}

${ }^{*} \mathrm{~T} 1$ = without breaking dormancy; $\mathrm{T} 2=$ Gibberellic acid $\left(200 \mathrm{mg} \mathrm{L}^{-1}\right)$ for one hour; $\mathrm{T} 3=$ Stratification at $5{ }^{\circ} \mathrm{C}$ for 30 days; T4 = Immersion in water at room temperature for 24 hours; T5 $=$ Chemical scarification with sulfuric acid $(96 \%)$ for 5 minutes; $\mathrm{T} 6=$ Scarification sandpaper; $\mathrm{T} 7=\mathrm{Immersion}$ in hot water $\left(80^{\circ} \mathrm{C}\right)$ for 5 minutes.

** Averages with different letters, lower case in the same column and upper case in the same line differ by Tukey's test $(\alpha=0.05)$. 
Table 6. Germination (\%) and germination speed index (GSI) of Surinan cherry seeds (E. uniflora) according to the break dormancy technique.

\begin{tabular}{ccc}
\hline \multirow{2}{*}{ Treatment } & \multicolumn{2}{c}{ Surinan cherry } \\
\cline { 2 - 3 } & Germination (\%) & GSI \\
\hline T1* & $98.82 \mathrm{a}^{* *}$ & $13.84 \mathrm{~b}^{* *}$ \\
T2 & $96.09 \mathrm{a}$ & $16.03 \mathrm{a}$ \\
T3 & $43.82 \mathrm{~b}$ & $1.66 \mathrm{c}$ \\
T4 & $98.10 \mathrm{a}$ & $14.50 \mathrm{ab}$ \\
T5 & $0.00 \mathrm{c}$ & $0.00 \mathrm{~d}$ \\
T6 & $95.35 \mathrm{a}$ & $13.41 \mathrm{~b}$ \\
T7 & $0.03 \mathrm{c}$ & $0.01 \mathrm{~d}$ \\
\hline CV (\%) & 12.15 & 7.87 \\
\hline
\end{tabular}

${ }^{*} \mathrm{~T} 1=$ whitout breaking dormancy; $\mathrm{T} 2=$ Gibberellic acid $\left(200 \mathrm{mg} \mathrm{L}^{-1}\right)$ for one hour; $\mathrm{T} 3=$ Stratification at $5{ }^{\circ} \mathrm{C}$ for 30 days; T4 = Immersion in water at room temperature for 24 hours; T5 $=$ Chemical scarification with sulfuric acid (96\%) for 5 minutes; $\mathrm{T} 6=$ Scarification sandpaper; $\mathrm{T} 7=$ Immersion in hot water $\left(80^{\circ} \mathrm{C}\right)$ for 5 minutes.

** Averages with different letters, lower case in the same column and upper case in the same line differ by Tukey's test $(\alpha=0.05)$.

Table 7. Germination time (days) of hybrid "jabuticaba" (P. cauliflora) and "guabiju" (M. pungens) seeds, according to the break dormancy technique and photoperiod ( 0 and 24 hours).

\begin{tabular}{c|cc|cc}
\hline \multirow{2}{*}{ Treatment } & \multicolumn{2}{|c|}{ Hybrid “Jabuticaba” } & \multicolumn{2}{c}{ “Guabiju” } \\
\cline { 2 - 6 } & 0 hours & 24 hours & 0 hours & 24 hours \\
\hline T1* & $33.87 \mathrm{c} \mathrm{A}^{* *}$ & $30.56 \mathrm{~b} \mathrm{~A}$ & $32.75 \mathrm{~b} \mathrm{~A}$ & $27.70 \mathrm{c} \mathrm{B}$ \\
T2 & $43.33 \mathrm{~b} \mathrm{~A}$ & $27.55 \mathrm{~b} \mathrm{~B}$ & $28.40 \mathrm{bcd} \mathrm{A}$ & $26.04 \mathrm{c} \mathrm{A}$ \\
T3 & $21.56 \mathrm{e} \mathrm{A}$ & $19.59 \mathrm{c} \mathrm{A}$ & $30.26 \mathrm{bc} \mathrm{A}$ & $33.52 \mathrm{~b} \mathrm{~A}$ \\
T4 & $28.95 \mathrm{~cd} \mathrm{~A}$ & $28.70 \mathrm{~b} \mathrm{~A}$ & $23.87 \mathrm{~d} \mathrm{~A}$ & $25.37 \mathrm{c} \mathrm{A}$ \\
T5 & $77.00 \mathrm{a} \mathrm{A}$ & $77.00 \mathrm{a} \mathrm{A}$ & $70.00 \mathrm{a} \mathrm{A}$ & $70.00 \mathrm{a} \mathrm{A}$ \\
T6 & $23.77 \mathrm{de} \mathrm{B}$ & $28.77 \mathrm{~b} \mathrm{~A}$ & $27.31 \mathrm{~cd} \mathrm{~A}$ & $25.05 \mathrm{c} \mathrm{A}$ \\
T7 & $77.00 \mathrm{a} \mathrm{A}$ & $77.00 \mathrm{a} \mathrm{A}$ & $31.19 \mathrm{bc} \mathrm{A}$ & $26.52 \mathrm{c} \mathrm{B}$ \\
\hline CV (\%) & \multicolumn{3}{c}{7.42} \\
\hline
\end{tabular}

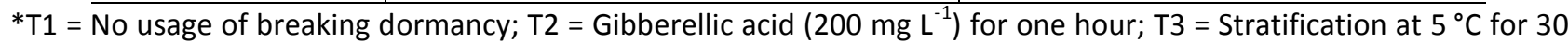
days; T4 = Immersion in water at room temperature for 24 hours; T5 = Chemical scarification with sulfuric acid (96\%) for 5 minutes; $\mathrm{T} 6=$ Scarification sandpaper; $\mathrm{T} 7=\mathrm{Immersion}$ in hot water $\left(80^{\circ} \mathrm{C}\right)$ for 5 minutes.

** Averages with different letters, lower case in the same column and upper case in the same line differ by Tukey's test $(\alpha=0.05)$.

Table 8. Germination time (days) of Surinan cherry (E. uniflora) and "sete capoteiro" (C. guazumifolia) seeds, according to the break dormancy technique and photoperiod ( 0 and 24 hours).

\begin{tabular}{c|cc|cc}
\hline \multirow{2}{*}{ Treatment } & \multicolumn{2}{|c|}{ Surinan cherry } & \multicolumn{2}{c}{ "Sete capotes" } \\
\cline { 2 - 5 } & 0 hours & 24 hours & 0 hours & 24 hours \\
\hline T1* & $18.70 \mathrm{~d} \mathrm{~A}^{* *}$ & $18.22 \mathrm{c} \mathrm{A}$ & $51.65 \mathrm{c} \mathrm{A}^{* *}$ & $32.50 \mathrm{~b} \mathrm{~B}$ \\
T2 & $17.59 \mathrm{~d} \mathrm{~A}$ & $18.64 \mathrm{c} \mathrm{A}$ & $52.74 \mathrm{bc} \mathrm{B}$ & $189.00 \mathrm{a} \mathrm{A}$ \\
T3 & $37.57 \mathrm{c} \mathrm{A}$ & $32.09 \mathrm{~b} \mathrm{~B}$ & $46.63 \mathrm{~d} \mathrm{~B}$ & $189.00 \mathrm{a} \mathrm{A}$ \\
T4 & $17.18 \mathrm{~d} \mathrm{~A}$ & $18.67 \mathrm{c} \mathrm{A}$ & $56.05 \mathrm{~b} \mathrm{~B}$ & $189.00 \mathrm{a} \mathrm{A}$ \\
T5 & $77.00 \mathrm{a} \mathrm{A}$ & $77.00 \mathrm{a} \mathrm{A}$ & $189.00 \mathrm{a} \mathrm{A}$ & $189.00 \mathrm{a} \mathrm{A}$ \\
T6 & $19.06 \mathrm{~d} \mathrm{~A}$ & $19.54 \mathrm{c} \mathrm{A}$ & $51.55 \mathrm{c} \mathrm{A}$ & $34.00 \mathrm{~b} \mathrm{~B}$ \\
T7 & $46.14 \mathrm{~b} \mathrm{~B}$ & $77.00 \mathrm{a} \mathrm{A}$ & $189.00 \mathrm{a} \mathrm{A}$ & $189.00 \mathrm{a} \mathrm{A}$ \\
\hline CV (\%) & \multicolumn{3}{|c}{4.47} \\
\hline
\end{tabular}

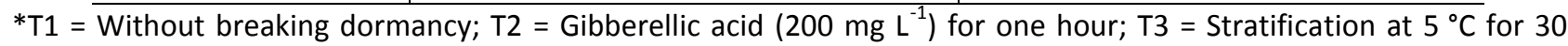
days; $\mathrm{T} 4$ = Immersion in water at room temperature for 24 hours; T5 = Chemical scarification with sulfuric acid (96\%) for 5 minutes; $\mathrm{T} 6=$ Scarification sandpaper; $\mathrm{T} 7=\mathrm{Immersion}$ in hot water $\left(80^{\circ} \mathrm{C}\right)$ for 5 minutes.

** Averages with different letters, lower case in the same column and upper case in the same line differ by Tukey's test $(\alpha=0.05)$. 
Table 9. Germination time (days) of native "jabuticaba" (P. peruviana) and Rio Grande cherry (E. involucrata) seeds, according to the technique to break dormancy.

\begin{tabular}{l|c|c}
\hline Treatment & Native “Jabuticaba” & Rio Grande cherry \\
\hline T1* & $26.48 \mathrm{c}^{* *}$ & $27.75 \mathrm{c}^{* *}$ \\
T2 & $25.56 \mathrm{c}$ & $27.56 \mathrm{c}$ \\
T3 & $77.00 \mathrm{a}$ & $38.11 \mathrm{~b}$ \\
T4 & $31.23 \mathrm{~b}$ & $27.38 \mathrm{c}$ \\
T5 & $77.00 \mathrm{a}$ & $70.00 \mathrm{a}$ \\
T6 & $27.34 \mathrm{c}$ & $26.83 \mathrm{c}$ \\
T7 & $77.00 \mathrm{a}$ & $70.00 \mathrm{a}$ \\
\hline CV (\%) & 3.86 & 2.74 \\
\hline
\end{tabular}

${ }^{*} \mathrm{~T} 1=$ Without breaking dormancy; $\mathrm{T} 2=$ Gibberellic acid $\left(200 \mathrm{mg} \mathrm{L}^{-1}\right)$ for one hour; $\mathrm{T} 3=$ Stratification at $5{ }^{\circ} \mathrm{C}$ for 30 days; T4 = Immersion in water at room temperature for 24 hours; T5 = Chemical scarification with sulfuric acid (96\%) for 5 minutes; $\mathrm{T} 6=$ Scarification sandpaper; $\mathrm{T} 7=1 \mathrm{mmersion}$ in hot water $\left(80^{\circ} \mathrm{C}\right)$ for 5 minutes.

** Averages with different letters, lower case in the same column and upper case in the same line differ by Tukey's test $(\alpha=0.05)$.

Table 10. Average germination time (days) of native "jabuticaba" ( $P$. peruviana) seeds, according to photoperiod ( 0 and 24 hours).

\begin{tabular}{c|c}
\hline Photoperiod & Native "jabuticaba" \\
\hline $0 \mathrm{hs}$ & $41.47 \mathrm{~b}^{* *}$ \\
$24 \mathrm{hs}$ & $42.71 \mathrm{a}$ \\
\hline $\mathrm{CV}(\%)$ & 3.86 \\
\hline
\end{tabular}

${ }^{* *}$ Averages with different letters in the same line differ by Tukey's test $(\alpha=0,05)$.

For the "sete capoteiro" germination (Table 2), there was superiority in the seeds that were kept in the dark, except for treatments 5 [chemical scarification with sulfuric acid (96\%) for 5 minutes] and 7 [immersion in hot water $\left(80^{\circ} \mathrm{C}\right)$ for 5 minutes] which were statistically similar to each other, as there was no seedling.

It is possible that the use of sulfuric acid and hot water may have damaged the seed embryo, compromising the germination process. This fact was also observed in the Rio Grande cherry, hybrid and native "jabuticabas" (Tables 2 and 3 ) and Surinan cherry (Table 6) seeds.

Rolston (1978) reports that the action of sulfuric acid on the seed embryo can be harmful, since the chemical scarification promotes the degradation of the integument and the increase in the immersion period can cause rupture of essential cells, which favors the mechanical injuries and the invasion of fungi, thus impairing emergency.

On the other hand, Dias et al. (2009) describes that the action of hot water, especially at temperatures of $85{ }^{\circ} \mathrm{C}$, can also affect the embryo's viability. For the author, hot water can compromise the seed embryo, however, an interesting fact was that in guabiju seeds (Table
3), only the application of sulfuric acid was harmful.

This negative effect of the sulfuric acid usage to break dormancy in seeds was also verified by Dousseau et al. (2007) for Zeyheria montana and Yamashita and Alberguini (2011) with Vernonia ferruginea seeds.

This demonstrated that the application of sulfuric acid and hot water to the seeds of these native fruit trees should be used, more carefully, and other concentrations and application times should be tested or perhaps it is necessary the use of treatment with a basic solution to neutralize this acid after its application.

The results with "sete capoteiro" seeds (Tables 2 and 4) inferred that they have negative photoblastic behavior, since when light was used, there was practically no germination. According to Kendrick and Frankland (1983) and Smith (1982), what regulates the germination of positive and negative photoblastic seeds is the balance between extreme red phytochrome and red phytochrome. Thus, in the case of negatives, it is necessary to have an amount of extreme red phytochrome below the level considered critical for germination. 
The "sete capoteiro" seeds that were submitted to the dark showed superiority when the use of scarification by wet sandpaper, immersion in gibberellic acid $\left(200 \mathrm{mg} \mathrm{L}^{-1}\right)$, immersion in water at room temperature and together with the witness, without any break in dormancy (Table 2). The same occurred with the results of the GSI of this native fruit tree (Table $4)$.

In both variables analyzed, a low percentage of seedlings was observed, suspecting that there is another mechanism that controls the germination process, in addition to the photoperiod, such as the presence of supposed morphological dormancy, which is related to the immaturity of the embryo.

In a work carried out by Santos (2003), with seeds of Campomanesia guazumifolia ("sete capoteiro") and Campomanesia xanthocarpa ("guabiroba" fruit), it was found the presence of many physiologically immature embryos, even with the fruits being visually mature. This confirms the hypothesis of morphological dormancy verified, mainly because the germination of the seeds of the "sete capoteiro" was slow, starting 60 days after sowing, and the evaluation could only be carried out after 126 days. Likewise, Santos et al. (2004) found that the germination of these species occurred 90 days after sowing, ranging of 102 to 167 days.

Rio Grande cherry seeds germination did not differ statistically regardless the technique, and independent of the presence or absence of light, except for the use of stratification at $5{ }^{\circ} \mathrm{C}$, which showed to be superior to the dark (Table 2). The same occurred with the GSI, however, scarification with sandpaper was also greater in the absence of light (Table 4). The immersion techniques of Rio Grande cherry seeds in gibberellic acid $\left(200 \mathrm{mg} \mathrm{L}^{-1}\right)$ and in water and, the scarification with sandpaper together with the treatment without application of the breaking dormancy techniques, presented the greatest germination averages, both in the presence and in the absence of light.

This same superiority of the described techniques was obtained for the GSI in the absence of light with this species (Table 4). On the other hand, when a 24 hour photoperiod was used, the highest GSI averages were obtained by immersing the seeds in gibberellic acid $\left(200 \mathrm{mg} \mathrm{L}^{-}\right.$ $\left.{ }^{1}\right)$ and in water and, scarification with sandpaper (Table 4).
It can be inferred that physical scarification through the use of sandpaper has allowed faster absorption of water by the seed, activating the resumption of embryo growth before the other techniques, which allowed greater expression of vigor in the seeds of the Rio Grande cherry. These advantages of seed scarification using sandpaper have already been highlighted by Borges and Rena (1993), when evaluating seeds of forest species.

Positive results with the use of gibberellic acid are because this substance can significantly increase the germination and the speed of this process in certain species, such as Pfaffia glomerata (RENNER et al., 2007), Annona cherimola Mill. X Annona squamosa L (OLIVEIRA et al., 2010), Vernonia ferruginea (YAMASHITA; ALBERGUINI, 2011).

Comparing the use of light for "guabiju", it was observed that the seeds kept in the dark showed greater germination when previously, the techniques of immersion in water with both room and hot temperature were adopted. The light supply for these seeds, on the other hand, showed superior results to those of the dark, in the absence of the techniques for breaking dormancy application (Table 3). Similar results were also observed by Santos et al. (2004), when analyzing the presence or absence of light in the germinative process of this fruit tree.

However, when analyzing each technique according to the supply or not of light, in "guabiju" seeds, greater germination was obtained when they were immersed in water at room temperature, in the absence and in the presence of light, with this technique usage together with immersion in gibberellic acid, and the treatment considered a witness (Table 3). The same result of superiority of these techniques in the presence or absence of light was obtained for the GSI (Table 5).

The adoption of a 24 hours photoperiod was superior for the germination of hybrid "jabuticaba" seeds, compared to those kept in the dark, within the techniques that presented germinated seeds. The same was obtained for native "jabuticaba" (Table 3 ).

In the seeds kept in the light, the techniques that proved to be superior for germination of the hybrid "jabuticaba" were using gibberellic acid, water at room temperature and scarification with sandpaper, as well as, without the adoption of any technique. In the native "jabuticaba", three of these techniques, 
except for immersing the seeds in water at room temperature for 24 hours, were superior for germination with the adoption of light (Table 3).

According to Hilhorst and Karssen (1988),

light is linked to the activation of the phytochrome system, which is related to changes in the cell membranes permeability, which in its turn may change the flow of numerous substances in cells, contributing to breaking the dormancy.

In the hybrid "jabuticaba" seeds kept in the dark, higher germination was obtained with those previously kept in the cold $\left(5^{\circ} \mathrm{C}\right)$ for 30 days and using sandpaper (Table 3 ). The same superior result with these techniques, keeping the seeds in the dark was obtained for the GSI. However, in the presence of light, stratification at $5{ }^{\circ} \mathrm{C}$ for 30 days was superior for GSI compared to the others (Table 5).

For native "jabuticaba", in the absence of light, the techniques that resulted in superior germination were immersion of the seeds in gibberellic acid and in water at room temperature, through scarification with sandpaper, and without using any technique for breaking dormancy (Table 3). A similar result of the superiority of these techniques was obtained for the GSI of native "jabuticaba" seeds in the presence and absence of light, except only for their immersion in water, which it was not among the high averages (Table 5). Thus, native jaboticaba seeds do not need any treatment for breaking dormancy.

For the Surinan cherry, the best results for seed germination were with the use of gibberellic acid $\left(200 \mathrm{mg} \mathrm{L}^{-1}\right.$ ) for one hour; immersion in water at room temperature for 24 hours and with scarification with sandpaper, however, these did not differ from the control (Table 6). For the GSI, the best results were with gibberellic acid (200 $\mathrm{mg} \mathrm{L}^{-1}$ ) for one hour, followed by immersion in water at room temperature for 24 hours (Table $6)$, differentiating in this case from the witness.

For the hybrid jabuticaba, the lowest TMG in the absence of the photoperiod occurred with stratification at $5{ }^{\circ} \mathrm{C}$ for 30 days and with the scarification with sandpaper. With a 24 hours photoperiod, the smallest TMG was stratified at 5 ${ }^{\circ} \mathrm{C}$ for 30 days (Table 7 ).

For the "guabiju", the lowest TMG in the absence of light, was with the use of gibberellic acid $\left(200 \mathrm{mg} \mathrm{L}^{-1}\right.$ ) for one hour, immersion in water at room temperature for 24 hours and scarification with sandpaper. Under a 24 hours photoperiod, best results were obtained with gibberellic acid $\left(200 \mathrm{mg} \mathrm{L}^{-1}\right)$ for one hour, seed immersion in water at room temperature for 24 hours, scarification with sandpaper, seed immersion in hot water $\left(80{ }^{\circ} \mathrm{C}\right)$ for 5 minutes, however, these did not differ from the control treatment (Table 7).

For Surinan cherry seeds, the lowest TMG results, both in the absence or presence of light, were gibberellic acid $\left(200 \mathrm{mg} \mathrm{L}^{-1}\right)$ for one hour, seed immersion in water at room temperature for 24 hours, scarification with sandpaper. However, they did not differ from the control treatment (Table 8).

Regarding "sete capoteiro" seeds, in the absence of the photoperiod, the lowest TMG occurred with stratification at $5{ }^{\circ} \mathrm{C}$ for 30 days. Under the 24 hours photoperiod, the lowest TMG occurred with the scarification with wet sandpaper and the control treatment. No germination occurred with the other treatments (Table 8).

For the native "jabuticaba" seeds, the treatments for breaking dormancy with lower TMG were gibberellic acid $\left(200 \mathrm{mg} \mathrm{L}^{-1}\right)$ for one hour, scarification with wet sandpaper and control. The seeds showed lower TMG in the absence of light (Tables 9 and 10).

In reference to Rio Grande cherry seeds, lower TMG was obtained with the use of gibberellic acid $\left(200 \mathrm{mg} \mathrm{L}^{-1}\right)$ for one hour, scarification with wet sandpaper, immersion in water at room temperature for 24 hours and the control treatment (Table 9).

For Passifloraceous seeds, specific treatments applied to the seed coat that cause their rupture, can reduce necessary time for germination, and consequently, reduce the time for seedling emergence (ALEXANDRE et al., 2009). The same rupture could explain a positive effect, in the present experiment, of using scarification with sandpaper on some native species seeds.

It was observed that each species showed accumulated germination (Figure 1) with an increase in the percentage of seeds germinated up to a certain period, basically until the $35^{\text {th }}$ day, stabilizing after this period. The exception was "sete capoteiro" in which germination started at 120 days, and in the absence of the photoperiod, there was more accumulated germination than with a 24 hours photoperiod. 
Figure 1. Accumulated germination (\%) of Rio Grande cherry (A and B), "guabiju" (C and D), hybrid "jabuticaba" (E and F), native "jabuticaba" (G and H), Surinan cherry (I and J), "sete capoteiro" (K and L) seeds, according with the photoperiod ( 0 and 24 hours) and treatments to break dormancy. T1 - No dormancy breaking usage; T2 - $\left(200 \mathrm{mg} \mathrm{L}^{-1}\right)$ for one hour; T3 - Stratification at $5{ }^{\circ} \mathrm{C}$ for 30 days; T4 Immersion in water at room temperature for 24 hours; T5 - chemical scarification with sulfuric acid (96\%) for 5 minutes; T6 - scarification with sandpaper; T7 - Soaking in hot water $\left(80^{\circ} \mathrm{C}\right)$ for 5 minutes.
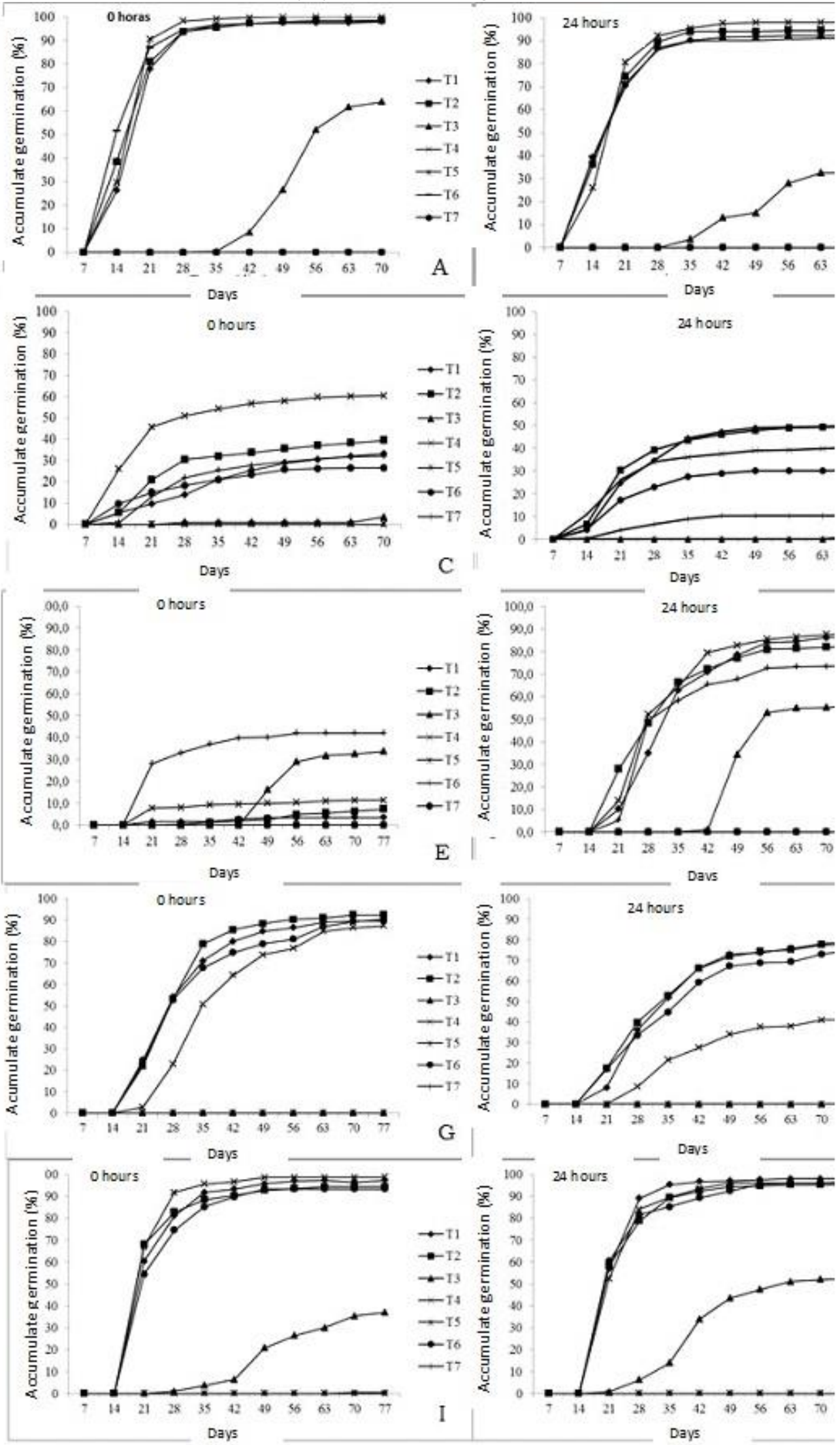


\section{Conclusions}

Most of the studied Brazilian native fruit seeds do not have dormancy or the effect of photoblastism, except for "sete capoteiro" ( $C$. guazumifolia), which are supposed to have morphophysiological dormancy, with negative photoblastism. The hot water or sulfuric acid usage in the seeds of native fruit trees is not recommended.

\section{References}

ALEXANDRE, R.S.; BRUCKNER, C.H.; LOPES, J.C. Propagação do maracujazeiro: aspectos morfológicos, fisiológicos e genéticos. Vitória: EDUFES, 2009. 208p.

ALEXANDRE, R.S.; WAGNER JÚNIOR, A.; NEGREIROS, J.R.S.; BRUCKNER, C.H.; FRANZON, R.C. Efeito do estádio de maturação dos frutos e de substratos na germinação de sementes e desenvolvimento inicial de plântulas de jabuticabeira. In: SIMPÓSIO NACIONAL DO MORANGO, 2. Encontro de pequenas frutas e frutas nativas do Mercosul, 2004, Pelotas. Anais [...]. Pelotas: Embrapa Clima Temperado, 2004. p.422-427.

ANDRADE, A.C.S.; LOUREIRO, M.B.; SOUZA, A.D.O.; RAMOS, F.N. Quebra de dormência de sementes de sucupira-preta. Pesquisa Agropecuária Brasileira, v.32, n.5, p.465-469, 1997.

ANDRADE, R.A.; MARTINS, A.B.G. Influence of the temperature in germination of seeds of jabuticaba tree. Revista Brasileira de Fruticultura, v.25, n.1, p.197-198, 2003. https://doi.org/10.1590/s010029452003000100056

BORGES, E.E.L.; BORGES, R.C.G.; CANDIDO, J.F.; GOMES, J.M. Comparação de métodos de quebra de dormência em sementes de copaíba. Revista Brasileira de Sementes, v.4, n.1, p.9-12. 1982. https://doi.org/10.17801/0101-3122/rbs.v4n1p9$\underline{12}$

BORGES, E.E.L.; RENA, A.B. Germinação de sementes. In: AGUIAR, I.B.; PIÑA-RODRIGUES, F.C.M.; FIGLIOLIA, M.B. Sementes florestais tropicais. Brasília: Abrates, 1993. p. 83-135.
BRASIL. Ministério da Agricultura, Pecuária e Abastecimento. Regras para Análise de Sementes. Brasília, DF: Mapa/ACS, 2009. 395p.

DIAS, D.C.F.S. Dormência em sementes: mecanismo de sobrevivência das espécies. Seed News, v.9, n.4, p.24-28, 2005.

DIAS, J.R.M. CAPRONI, A.L.; WADT, P.G.S.; SILVA, L.M.; TAVELLA, L.B.; OLIVEIRA, J.P. Quebra de dormência em diásporos de teca (Tectona grandis L.f.). Acta Amazonica, v.39, n.3, p.549-554. 2009. https://doi.org/10.1590/S0044$\underline{59672009000300009}$

DOUSSEAU, S.; ALVARENGA, A.A.; CASTRO, E.M.; ARANTES, L.O.; NERY, F.C. Superação de dormência em sementes de Zeyheria montana Mart. Ciência e Agrotecnologia, v.31, p.17441748, 2007. https://doi.org/10.1590/S1413$\underline{70542007000600021}$

FOWLER, J.A.P.; BIANCHETTI, A. Dormência em sementes florestais. Colombo: EMBRAPAFlorestas, 2000. 27 p. (Doc.; 40).

FRANZON, R.C. Propagação vegetativa e modo de reprodução da pitangueira (Eugenia uniflora L.). 2008. 100f. Dissertação (Mestrado) Universidade Federal de Pelotas, Pelotas, 2008.

HILHORST, H.W.M.; KARSSEN, C.M. Dual effects of light on the gibberelin and nitrate- stimulated seed germination of Sisymbrium officinale and Arabidopsis thaliana. Plant Physiology, v.86, n.3, p.591-597. 1988. https://doi.org/10.1104/pp.86.2.591

HOSSEL, C.; OLIVEIRA, J.S.M.A.; FABIANE, K.C.; WAGNER JÚNIOR, A.; CITADIN, I. Conservação e teste de tetrazólio em sementes de jabuticabeira. Revista Brasileira de Fruticultura, v.35, n.1, p.255-261, 2013. https://doi.org/10.1590/S0100$\underline{29452013000100029}$

KENDRICK, R.E.; FRANKLAND, B. Phytochrome and Plant Growth. 2. ed. London: Edward Arnold, 1983. 73p.

MAGUIRE, J.D. Speeds of germination-aid selection and evaluation for seedling emergence and vigor. Crop Science, v.2, p.176-177, 1962. 
https://doi.org/10.2135/cropsci1962.0011183X0 $\underline{00200020033 x}$

OLIVEIRA, M.C.; FERREIRA, G.; GUIMARÃES, V.F.; DIAS, G.B. Germinação de sementes de atemoia (Annona cherimola Mill. X A. squamosa L.) 'Gefner' submetidas a tratamentos com ácido giberélico (GA3) e ethephon. Revista Brasileira de Fruticultura, v.32, n.2, p.544-554, 2010. https://doi.org/10.1590/S0100-

$\underline{29452010005000062}$

PIÑA-RODRIGUES, F.C.M.; AGUIAR, I.B. Maturação e dispersão de sementes. In: AGUIAR, I.B.; PIÑA-RODRIGUES, F.C.M.; FIGLIOLIA, M.B. Sementes florestais tropicais. Brasília: ABRATES, p. 83-135, 1993.

RENNER, G.D.R.; CAMACHO, F.; PEIXE, S. Ação da temperatura, ácido giberélico e luz na germinação de sementes de fáfia - Pfaffia glomerata (Spreng.). Semina: Ciências Agrárias, v.28, p.349-354. 2007. https://doi.org/10.5433/1679$\underline{0359.2007 v 28 n 3 p 349}$

ROLSTON, M.P. Water impermeable seed dormancy. The botanical Review, v.44, n.33, p.365-396, 1978. https://doi.org/10.1007/BF02957854

SANTOS, C.M.R.; FERREIRA, A.G.; ÁQUILA, M.E.A. Características de frutos e germinação de sementes de seis espécies de Myrtaceae nativas do Rio Grande do Sul. Ciência Florestal, v.14, n.2, p.13-20, 2004. https://doi.org/10.5902/198050981802

SANTOS, C.M.R. Myrtaceae - análises morfológicas e do efeito da temperatura e da luz na germinação de sementes de espécies nativas do Rio Grande do Sul. 2003. Dissertação (Mestrado) - Universidade Federal do Rio Grande do Sul, Porto, 2003.
SENA, L.H.M.; MATOS, V.P.; FERREIRA, E.G.B.S.; SALES, A.G.F.A.; PACHECO, M.V. Qualidade fisiológica de sementes de pitangueira submetidas a diferentes procedimentos de secagem e substratos - Parte 1. Revista Brasileira de Engenharia Agrícola e Ambiental, v.14, n.4, p.405-411, 2010. https://doi.org/10.1590/S1415$\underline{43662010000400009}$

SILVA, J.B.C.; NAKAGAWA, J. Estudo de fórmulas para o cálculo da velocidade de germinação. Informativo ABRATES, v.5, n.1, p.62-73, 1995.

SMITH, H. Light quality photoperception and plant strategy. Annual Review of Plant Physiology, v.33, p.481-518, 1982. https://doi.org/10.1146/annurev.pp.33.060182.0 $\underline{02405}$

VALIO, I.F.M.; FERREIRA, Z.L. Germination of seeds of Myrciaria cauliflora (Mart.) Berg. (Myrtaceae). Revista Brasileira de Fisiologia Vegetal, v.4, n.2, p.95-98, 1992.

WAGNER JÚNIOR, A.; FRANZON, R.C.; SILVA, J.O.C.; SANTOS, C.E.M.; GONÇALVES, R.S.; BRUCKNER, C.H. Efeito da temperatura na germinação de sementes de três Espécies de jabuticabeira. Revista Ceres, v.54, n.314, p.345350, 2007.

WAGNER JÚNIOR, A.; SILVA, J.O.C.; PIMENTEL, L.D.; SANTOS, C.E.M.; BRUCKNER, C.H. Germinação e desenvolvimento inicial de duas espécies de jabuticabeira em função do tamanho de sementes. Acta Scientiarum Agronomy, v.33, n.1, p.105-109. 2011. https://doi.org/10.4025/actasciagron.v33i1.4881

YAMASHITA, O.M.; ALBERGUINI, A.L. Germinação de Vernonia ferruginea em função da quebra de dormência, luminosidade e temperatura. Comunicata Scientiae, v.2, n.3, p.142-148, 2011.

ZONTA, E.P.; MACHADO, A.A. Sanest - Sistema de Análise Estatística para Microcomputadores. Pelotas: UFPel, 1984. 75p. 